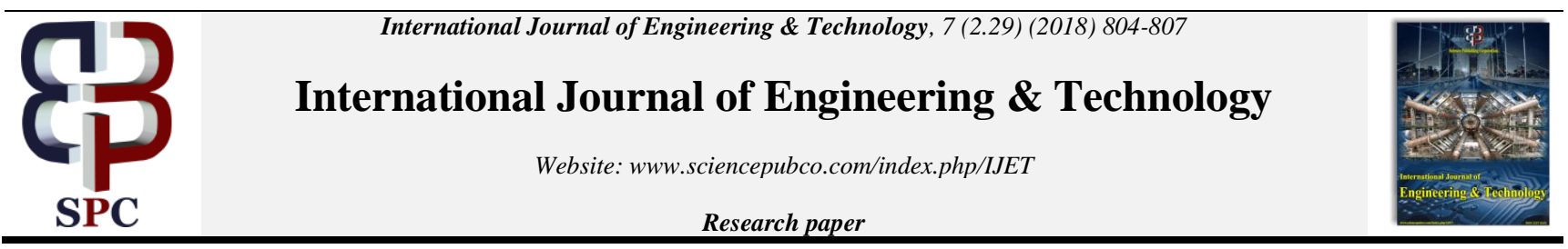

\title{
The Designing Criteria and Sub-Criteria of University Balance Scorecard Using Analytical Hierarchy Process Method
}

\author{
Satria Abadi ${ }^{1 *}$, Setyawan Widyarto ${ }^{2}$ \\ ${ }^{1}$ Information System Department Sekolah Tinggi Manajemen Informatika Dan Komputer (STMIK) Pringsewu, Lampung-Indonesia \\ ${ }^{2}$ Faculty Of Communication, Visual Art And Computing (FCVAC) Universiti Selangor, Selangor - Malaysia \\ *Corresponding Author E-Mail: Satria2601@Gmail.Com
}

\begin{abstract}
Universities have an important role in determining the progress and prosperity of a nation. In connection with this progress, the social demand for accountability of higher education also emerged broadly, therefore, the college should be able to compete to improve the quality of all aspect's college business strategy both internally and externally. A university accountability can be seen from the performance measurement of the college, the aim of this study is to design sub-criteria and of performance measurement of a university to improve the quality of higher education in the district Pringsewu Lampung. The design will use the Balanced Scorecard and Analytical Hierarchy Process. Balance Scorecard method is a method that has the ability to analyse leading indicators and lagging indicators. Lagging indicators consist of a financial perspective while Leading indicators consist of the internal business process, learning and growth, customer. While Analytical Hierarchy process is a method that determines the best alternative amongst the chosen criteria and subcriteria will be ranked, started from the highest score, thus, it will become benchmark percentage to determine the value range from the highest to the lowest. The criteria and sub-criteria of this study are the four main criteria taken the perspective of balance scorecard, Internal Business, Customer, financial, Learning and Growth, whereas, the 9 sub-criteria used to measure the performance are taken from higher education in the region Pringsewu.
\end{abstract}

Keywords: Performance; performance colleges; balance Scorecard; AHP

\section{Introduction}

The college is a strength that exists in today's society that can change the mindset to become more democratic and able to compete in the era of global technology. The college also has credibility in the construction of a state, For that, the government opened up opportunities in every region in Indonesia to establish the college is no exception in the region Pringsewu one district that located in the area of Lampung. In the district of Pringsewu, has eight universities and one vocation. www.kopertis2.go.id

Their colleges in the region to facilitate the public Pringsewu will pursue higher education in the region Pringsewu for this community college continuing education should be elsewhere. As an institution that is the source of knowledge as well as a container or a place that produces people who have the knowledge to make the ad institution of higher learning in the region Pringsewu further enhance accountability to the community college. Accountability is very easy to be seen colleges of higher education performance. accountability college will affect the college level performance measurement, performance measurement colleges greatly affecting the assessment of the college.

Accountability college will be reflected on the measurement of college performance. Measurements have college performance indicators or criteria of its own, to meet the need of these indicators at the strategic and synthesis of contemporary management concepts through the implementation of a higher one using a balanced scorecard. Advantages of the balanced scorecard (BSC) is an approach that can translate on the balance of an organisation's vision and strategy into objectives destination that can provide sustainable long and performance measurement through a perspec- tive that existed at the balance scorecard (1)

One method of making the ranking and screening indicator of performance indicator by using the method of decision-making in this case used the method Analytical Hierarchy Process (AHP). Analytic Hierarchy Process (AHP) since it was first introduced by Saaty in 1971, and has become one of the most widely used methods widely in multiple criteria decision-making methods (Multiple-Criteria Decision-Making). Analytic Hierarchy Process (AHP) as a decision-making tool to prioritise the perspective of multiple criteria and indicators and generate metrics for ranking the unification of alternatives exist.(2)

From the above references, it can be seen that the college must have accountability in the community. To have that accountability, some criteria and sub-criteria are needed to meet the standards of college performance. Those criteria and sub-criteria will be included in measuring the performance and the purpose of this study is to create criteria and sub-criteria. Balance scorecard with analytical hierarchy process method will be used in the measurement method.

\subsection{Research Questions}

The criteria and sub-criteria of this research are to design a university performance measurement by using Balanced Scorecard and Analytical Hierarchy Process. The questions in this research are divided into four sections:

1. How do we design criteria and sub-criteria of BSC College of four perspectives (Finance, Customer, Internal Business Processes, Learning and Growth) which can be implemented as a measure of performance universities in Pringsewu region? 
2. How do we integrate the concept of BSC framework and AHP to obtain the appropriate indicator in measuring the performance of higher education?

3. How can we sort each indicator viewed from the level of our interests?

\section{Literature Review}

\subsection{Balance Scorecard}

The concept of Balance ScoreCard (BSC) was originally developed by Robert Kaplan and David Norton at Harvard Business School in 1992. Then BSC became a popular and useful method to identify business performance by using lagging and leading indicators based on organizational vision and strategy. Problems arise if they identify that many organizations have a tendency to manage their business based solely on financial measurements. For this reason, business today requires large and comprehensive measurement. Kaplan and Norton (3)

The BSC is used as a tool to measure the performance of both public and private organizations to achieve business goals and strategies. Kaplan and Norton (3) define the Balance Score Card:

"a set of measures that gives top managers a fast but comprehensive view of the business...include financial measures that tel result of action already taken...complements the financial measures with operational measures on customer satisfaction, internal processes, and the organization's innovation and improvement activities-operational measures that are drivers of future financial performance".

This definition provides an understanding that BSC is a management system that includes measurement and control to describe the organization from 4 perspectives namely, financial, customer, internal process and growth and learning. These four perspectives have relationship and causality. The financial perspective is considered to have a result that moves the other three operational operational indicators. According to (4), the definition of BSC and Higher Education are:

1. Balance Scorecard refers to the performance management tools developed by Kaplan and Norton in 1992 (4)

2. Higher Education Organization refers to non-profit organization 2 year public and private high schools and 4 years for university. (4)

Kaplan and Norton (1) fundamentally developed a Scorecard consisting of 4 main perspective elements, namely:

\subsection{Customer Perspective}

This element measures customer satisfaction as a requirement that must be achieved.

\subsection{Internal Business Process Perspective:}

This perspective is used to measure the required and important process for the customers.

\subsection{Financial Perspective}

Financial Perspective: This element is used to measure financial and performance tracks that excel in organization.

\subsection{Learning and Growth Perspective}

This perspective will focus on how organizations provide training and education to their employees. It is also to acquire and capture their knowledge, and how organizations use the employees' knowledge to maintain competitive power into the marketplace. In addition, the specific elements of a scorecard depend on the organization's goals (vision, mission, and objectives). Kaplan and Norton (1) stated that BSC goals and indicators are based on a vision and strategy that can maintain a balance between long-term and short-term goals, financial and non-financial measurements, lagging and leading indicators, and external and internal performance perspectives. Kaplan and Norton (3) suggested a strategy map describing the main objectives and communicating strategy.

\subsection{Analytical hierarchy process (AHP)}

The AHP is an analysis tool that can be used to make decisions in situations of complex factors, especially if the decision is subjective. The AHP generates structured approach to determine the value and weight to the problems multi-criteria and make of each other in standardisation so that it can compare and can take a decision. The AHP can be used to obtain detailed knowledge of the human mind composing complex reality into portions being substantially element and then compile this section into parts again, and continue in hierarchy. (5)

The preparation of this hierarchy is the most important stage in the application of the AHP as a model of the desired problem solved. In compiling this hierarchy required creative thinking, information gathering, combining information, the process of remembering, a parent's perspective and also development. In practice, there is no standard procedure to establish objectives, criteria and other elements in the hierarchy. The composition of the hierarchy is multilinear and compile from top to bottom the factors that are most common and little can be controlled up to a factor that is the most common and little can be controlled up to a factor which is concrete and can be in control.

\section{Methodology}

\subsection{Research Design}

Research design is a depiction of the stages of work steps from beginning to end stages of research and the design of research can make the research process easier to conduct.

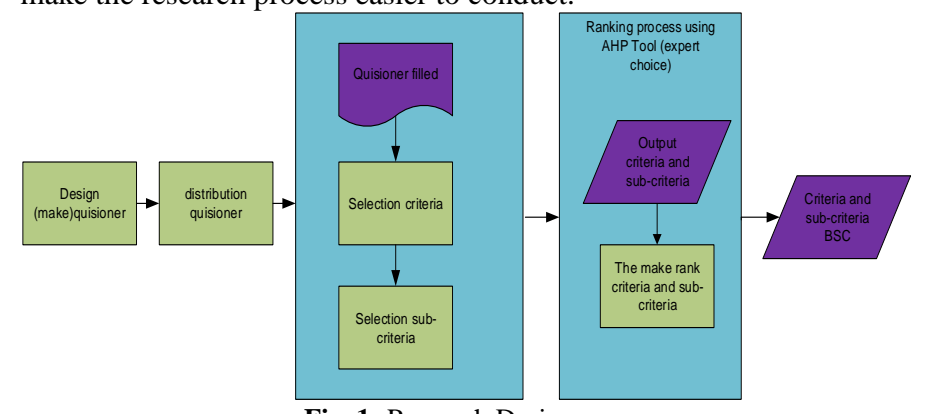

Fig. 1: Research Design

A serial steps in this research is based on Figure 1 and they are as the following:

1. The research started from the making of the questionnaire, a questionnaire was obtained from several references on the balanced scorecard

2. The next step is a questionnaire given to respondents, namely: leadership and management levels involved in decision making in universities concern and understanding of performance measurement. A questionnaire was administered through an online media (email, social networks, etc.) to decision-making in each college.

3. Once the questionnaires filled the next step to identify criteria and sub-criteria that have been selected for each respondent. Selected criteria and sub-criteria of this phase, the researchers will be invaluable to determine the total value. To determine the total value of the criteria of sub-criteria of researchers using the formula:

Total value $=75 \% \mathrm{X}\left(\sum\right.$ Respondent $\mathrm{X}$ Score Maximum $)$

4. The criteria and sub-criteria of will be selected as an indicator in determining performance if the total value of the criteria and sub-criteria is minimum (the smallest).

5. The indicator ranking of performance measurement in college in the area Pringsewu will be concluded. 


\section{Data Analysis}

The data processing carried out two stages, namely:

1. Combine the respondents' assessment of the stage of the relative importance of each criterion and sub-criteria. Ratings set in AHP can be combined into one average ratings through the geometry of the respondents' assessment. This assessment becomes the input for processing data using Expert Choice.

2. Thinking that weight is a virtue for each criterion and subcriteria and inconsistency ratio using Expert Choice.

Pairwise comparison matrix are geometrical average of the entire results of the respondent's answer. It means votes are calculated based on the geometrical average (6)

$\mathrm{R}=\left[\left(1+\mathrm{R}_{1}\right)\left(1+\mathrm{R}_{2}\right)\left(1+\mathrm{R}_{3}\right) \ldots \ldots(1+\mathrm{R} n)\right]^{1 / \mathrm{n}_{-}}$

Information:

$\mathrm{R} 1 \ldots \mathrm{R} \mathrm{n}=$ Decision retort respondent and respondent 1 to $\mathrm{n}$.

\section{Result}

\subsection{Criteria and sub Criteria}

This study focuses on the chosen criteria of sub-criteria and questionnaires were distributed amongst decision makers in the region of Pringsewu to obtain the results.

\subsection{Main criteria}

\section{Priorities with \\ BSC U niṽersity \\ $>$ Main Criteria}

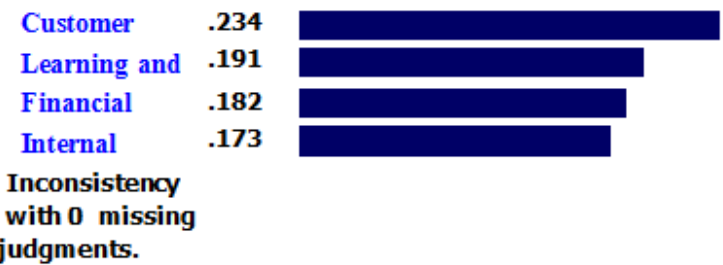

Fig. 2: Main Criteria

The main criteria are taken from four perspective Balance Scorecard. The highest value of all the four perspectives is Customer amongst all of them, Figure 2. This result shows that the customer is the most important criterion for increasing the accountability of universities

\subsection{Sub-Criteria}

In this study sub-criteria of scaled from four main criteria of which is taken from perspective Balance Scorecard, consists of sub-criteria of the Customer, sub-criteria of Learning And Growth, sub-criteria of the Financial and sub-criteria of Internal Business Process.

\subsection{Customer sub-criteria}

The Customer criterion has two sub-criteria, i.e. sub-criteria Quality of Graduates and the Quality of Information System. Although both are not too much the difference it is clear that the quality of graduates can be picked to measure the quality of higher education, Figure 3. Therefore, the quality of graduates is picked to promote accountability to universities.

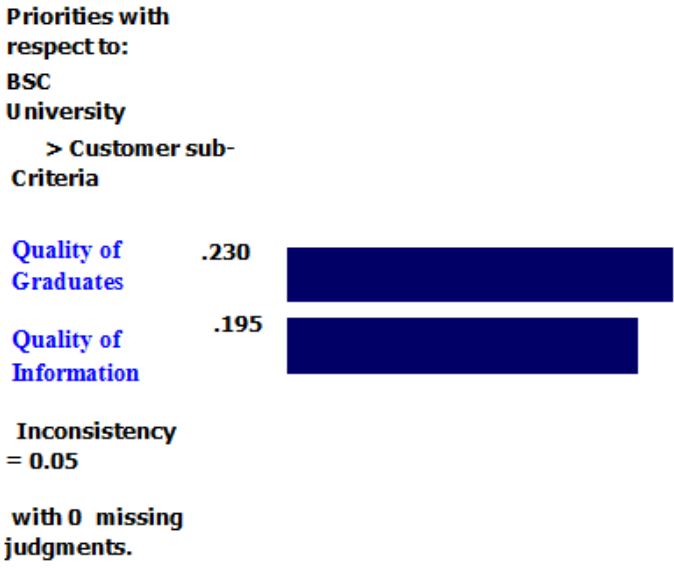

Fig. 3: Customer Sub-

\subsection{Learning and Growth Sub-}

The Learning and Growth criteria has two sub-criteria, i.e. Quality Insurance System and Quality of Planning. The quality of Insurance System is the highest, hence, it can be used as measurement of the quality of higher education, Figure 4

\section{Priorities with \\ respect to:}

BSC U niversity

$>$ Learning and $\mathrm{G}$ rowth

sub-Criteria

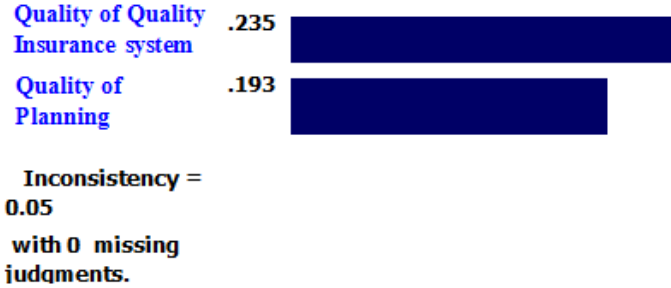

Fig. 4: Learning and Growth Sub-

\subsection{Financial Sub-Criteria}

The Financial criterion has three sub-criteria. The sub-criteria of Cost Focus has the highest value on the main criteria of Financial, Figure 5. This result indicates that Cost Focus can be selected as measurement of quality of higher education. The Cost Focus criterion shows that any existing activities in universities are capably funded if the activities establish to be accountable or in other words can be seen and controlled by the public.

\section{Priorities with \\ respect to:}

BSC U niversity

\section{$>$ Finacial \\ sub-Criteria}

Cost
Focus
Revenue
Focus
Training and
Development
Inconsistenc
y= 0.05
with 0 missing
judgments.

.206

169

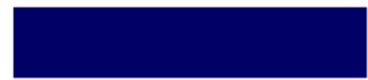

.156

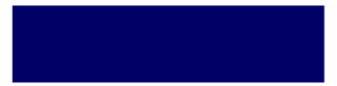

judgments. 


\subsection{Internal Business Process Sub-Criteria}

The Internal Business Process Criterion consists of two subcriteria, Quality of Lecture and Learning Support. Even though both of them are not significantly different, Quality of Lecturer is bigger than Learning Support criterion, Figure 6. Therefore, the Quality of Lecture can be one measuring sub-criterion of the quality of higher education. It could be explained that Lecture is one source of knowledge for students in the learning process and the lecture has a role in the process to produce qualified graduates. Priorities with respect

to:

BSC University

\section{> Internal Business process sub-Criteria}

\author{
Quality of Lec- \\ ture
}

Quality of Learnitgo

Support

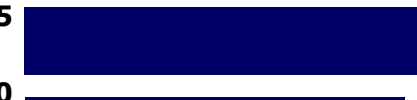

Inconsistency

$\mathbf{=} 0.05$

with 0 missing judg-

ments.

Fig. 6: Internal Business Process Sub-Criteria

\section{Conclusion}

The study has used four main criteria i.e. Customer, Learning and Growth, the Financial and Internal Business Process that are taken from perspective Balance scorecard. The main criteria that have the highest value are a customer with value of 0.234 , then learning growth having a weight of 0.191 , while 0.182 value for financial criterion, and the internal business process has a value of 0.173 . The research has used nine sub-criteria which are derived from primary criteria. Both sub-criteria of Quality Insurance System and Graduates have been the top two values amongst all of the nine, Figure 7.

\section{Main Criteria}

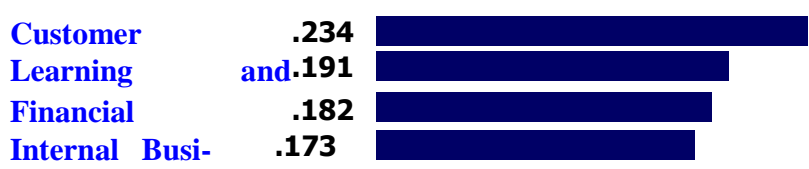

Sub-criteria

\section{Customer :}

Quality of Graduates

Quality of Infor-: .195 mation System

\section{Learning and Growth:}

Quality of Quality .235

surance System

Quality of Planning

.193

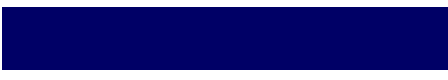

\section{Financial:}

Cost Focus

\section{.206}

Revenue

Focus

.169

9

Training and Develop- .156 ment Focus

\section{Internal Business process:}

Quality of Lecture

.195

Quality of Learning 190 Support

Fig. 7: Main Criteria and Sub-Criteria

\section{Acknowledgement}

This research was partially funded by Ministry of Higher Education (MoHE), Department of Higher Education (JPT), Institutions of Higher Education Excellence Planning Division (BPKI) Fundamental Research Grant Scheme (FRGS/1/2016/STG07/) - Pure and Applied Science.

\section{References}

[1] Robert S. Kaplan DPN. Putting the Balanced Scorecard to Work, Harvard Bussiness Review. 1993

[2] Bentes AV, Carneiro J, da Silva JF, Kimura H. Multidimensional assessment of organizational performance: Integrating $\mathrm{BSC}$ and AHP. Journal of Business Research. 2012;65(12):1790-9.

[3] Kaplan RS, Norton DP. Balanced Scorecard: Menerapkan Strategi Menjadi Aksi. Pasla PRY Penerjemah Jakarta: Erlangga. 2000.

[4] Brown C. Application of the Balanced Scorecard in Higher Education Opportunities and Challenges Planning for Higher Education. 2012;40(4).

[5] Saaty TL. Pengambilan keputusan bagi para pemimpin, proses hirarki analitik untuk pengambilan keputusan dalam situasi yang kompleks. Pustaka binama pressindo. 1993.

[6] Feridani E. Perancangan metode pembobotan kriteria pemilihan pemasok dengan metode analytic hierarchy process (ahp) dan fuzzy ahp:(studi kasus pemilihan pemasok jasa pemeliharaan fasilitas off shore di pt. x): FT-UI; 2005. 